\title{
Erythrobacter luteolus sp. nov., isolated from a tidal flat of the Yellow Sea in Korea
}

Correspondence

Jung-Hoon Yoon

jhyoon@kribb.re.kr

\author{
Jung-Hoon Yoon, ${ }^{1}$ Kook Hee Kang, ${ }^{2}$ Soo-Hwan $\mathrm{Yeo}^{3}$ \\ and Tae-Kwang $\mathrm{Oh}^{1}$ \\ ${ }^{1}$ Korea Research Institute of Bioscience and Biotechnology (KRIBB), PO Box 115, Yusong, \\ Taejon, Korea \\ ${ }^{2}$ Department of Food and Life Science, Sungkyunkwan University, Chunchun-dong 300, \\ Jangan-gu, Suwon, Korea \\ ${ }^{3}$ Center for Traditional Microorganism Resources, Keimyung University, Shindang-dong, \\ Dalseo-gu, Daegu, Korea
}

\begin{abstract}
A Gram-negative, non-spore-forming, yellow-pigmented, slightly halophilic bacterial strain, $\mathrm{SW}-109^{\top}$, was isolated from a tidal flat of the Yellow Sea in Korea, and subjected to a polyphasic taxonomic study. This isolate did not produce bacteriochlorophyll a and contained ubiquinone-10 as the predominant respiratory lipoquinone and $\mathrm{C}_{18: 1} \omega 7 \mathrm{C}$ as the major fatty acid. The DNA G $+\mathrm{C}$ content was $60.3 \mathrm{~mol} \%$. Phylogenetic analyses based on $16 \mathrm{~S}$ rRNA gene sequences showed that strain $\mathrm{SW}-109^{\top}$ is phylogenetically affiliated to the genus Erythrobacter of the family Sphingomonadaceae. Strain SW-109 ${ }^{\top}$ exhibited levels of $16 \mathrm{~S}$ rRNA gene sequence similarity to the type strains of Erythrobacter species of 94.0-96.3\%, making it possible to categorize strain $\mathrm{SW}-109^{\top}$ as a species that is separate from previously recognized Erythrobacter species. On the basis of its phenotypic properties and phylogenetic distinctiveness, SW $-109^{\top}\left(=\right.$ KCTC $12311^{\top}=$ JCM $\left.12599^{\top}\right)$ was classified as the type strain of a novel Erythrobacter species, for which the name Erythrobacter luteolus sp. nov. is proposed.
\end{abstract}

The genus Erythrobacter was proposed by Shiba \& Simidu (1982) and at the time of writing comprises seven species with validly published names: Erythrobacter longus (Shiba \& Simidu, 1982), Erythrobacter litoralis (Yurkov et al., 1994), Erythrobacter citreus (Denner et al., 2002), Erythrobacter flavus (Yoon et al., 2003), Erythrobacter aquimaris (Yoon et al., 2004), Erythrobacter seohaensis (Yoon et al., 2005) and Erythrobacter gaetbuli (Yoon et al., 2005). The first two Erythrobacter species were orange- and red- or orangepigmented and contained bacteriochlorophyll $a$ (BChl $a)$ (Shiba \& Simidu, 1982; Yurkov et al., 1994). However, two yellow-pigmented Erythrobacter species, E. citreus and E. flavus, lacking BChl $a$, have also been described (Denner et al., 2002; Yoon et al., 2003). In this study, we report on the taxonomic characterization of a slightly halophilic, yellow-pigmented Erythrobacter-like bacterial strain,

Published online ahead of print on 21 January 2005 as DOI 10.1099/ ijs.0.63522-0.

Abbreviation: BChl, bacteriochlorophyll.

The GenBank/EMBL/DDBJ accession number for the 16S rRNA gene sequence of strain SW-109' is AY739662.

A table giving the percentage cellular fatty acid content of Erythrobacter luteolus SW-109 ${ }^{\top}$ and type strains of Erythrobacter species is available as supplementary material in IJSEM Online.
SW $-109^{\mathrm{T}}$, which was isolated from sea water of a tidal flat of the Yellow Sea in Korea.

Strain $\mathrm{SW}-109^{\mathrm{T}}$ was isolated by the usual dilution-plating technique on marine agar 2216 (MA; Difco) at $30^{\circ} \mathrm{C}$. Cell morphology was examined by light microscopy (E600; Nikon) and transmission electron microscopy (TEM). The presence of flagella was determined by using TEM with cells from exponentially growing cultures. For transmission electron microscopic observation, the cells were negatively stained with $1 \%(\mathrm{w} / \mathrm{v})$ phosphotungstic acid and the grids were examined after air-drying with a Philips CM-20 transmission electron microscope. Growth under anaerobic conditions was determined after incubation in a Forma anaerobic chamber on MA and on MA supplemented with nitrate, both of which had been prepared anaerobically using nitrogen. Growth in the absence of $\mathrm{NaCl}$ was investigated in trypticase soy broth without $\mathrm{NaCl}$ (Difco). Growth at various $\mathrm{NaCl}$ concentrations was investigated in marine broth 2216 (MB; Difco) or trypticase soy broth (Difco). Growth at various temperatures $\left(4-40^{\circ} \mathrm{C}\right)$ was measured on MA. Catalase and oxidase activities and hydrolysis of casein, starch and Tweens 20, 40, 60 and 80 were determined as described by Cowan \& Steel (1965). Hydrolysis of hypoxanthine, tyrosine and xanthine was tested on MA using the substrate concentrations described 
by Cowan \& Steel (1965). Hydrolysis of aesculin, gelatin and urea and nitrate reduction were investigated as described by Lanyi (1987), with the modification that artificial sea water was used for preparation of media. The artificial sea water contained (per litre distilled water): $23.6 \mathrm{~g} \mathrm{NaCl}$, $0.64 \mathrm{~g} \mathrm{KCl}, 4.53 \mathrm{~g} \mathrm{MgCl}_{2} .6 \mathrm{H}_{2} \mathrm{O}, 5.94 \mathrm{~g} \mathrm{MgSO}_{4} .7 \mathrm{H}_{2} \mathrm{O}$ and $1 \cdot 3 \mathrm{~g} \mathrm{CaCl}_{2} \cdot 2 \mathrm{H}_{2} \mathrm{O}$ (Bruns et al., 2001). $\mathrm{H}_{2} \mathrm{~S}$ production was tested as described by Bruns et al. (2001). For in vivo pigment-absorption spectrum analysis, the strain was cultivated aerobically in the dark at $30^{\circ} \mathrm{C}$ in $\mathrm{MB}$ and Erythromicrobium/Roseococcus medium (Yurkov et al., 1994; DSMZ medium no. 767). E. longus DSM $6997^{\mathrm{T}}$ was used as a positive control for the spectrum analysis. The cultures were washed twice by centrifugation using a MOPS buffer (MOPS/NaOH, 0.01 M; KCl, 0.1 M; $\mathrm{MgCl}_{2}, 0.001 \mathrm{M}$; $\mathrm{pH} 7 \cdot 5)$ and were disrupted by sonication with a Branson Sonifier 450. After removal of cell debris by centrifugation, the absorption spectrum of the supernatant was examined on a Beckman Coulter DU800 spectrophotometer. Susceptibility to antibiotics was detected on MA plates by using antibiotic discs with the following concentrations; polymyxin
B (100 U), streptomycin $(50 \mu \mathrm{g})$, penicillin $\mathrm{G}(20 \mathrm{U})$, chloramphenicol $(100 \mu \mathrm{g})$, ampicillin $(10 \mu \mathrm{g})$, cephalothin $(30 \mu \mathrm{g})$, gentamicin $(30 \mu \mathrm{g})$, novobiocin $(5 \mu \mathrm{g})$ and tetracycline $(30 \mu \mathrm{g})$. Acid production from carbohydrates was determined as described by Leifson (1963). Utilization of various substrates for growth was determined as described by Yurkov et al. (1994).

Cell biomass for respiratory lipoquinone analysis and for DNA extraction was obtained by cultivation in $\mathrm{MB}$ at $30{ }^{\circ} \mathrm{C}$. Respiratory lipoquinones were analysed as described by Komagata \& Suzuki (1987) using reversed-phase HPLC. Chromosomal DNA was isolated and purified according to the method described by Yoon et al. (1996), with the exception that ribonuclease $\mathrm{T} 1$ was treated in combination with ribonuclease A to minimize the contamination of RNA. For fatty acid methyl ester (FAME) analysis, cell mass of strain $\mathrm{SW}-109^{\mathrm{T}}$ was harvested from agar plates after cultivation for 5 days at $30^{\circ} \mathrm{C}$ on MA. The FAMEs were extracted and prepared according to the standard protocol of the MIDI/Hewlett Packard Microbial

\section{Table 1. Differential phenotypic characteristics of Erythrobacter species}

Species: 1, E. luteolus sp. nov. $(n=1)$; 2, E. longus $(n=11)$ (data from Shiba \& Simidu, 1982); 3, E. litoralis ( $n=1)$ (Yurkov et al., 1994); 4, E. citreus ( $n=2)$ (Denner et al., 2002; Vybiral et al., 1999); 5, E. flavus ( $n=2)$ (Yoon et al., 2003); 6, E. aquimaris ( $n=3)$ (Yoon et al., 2004); 7, E. seohaensis $(n=1)$ (Yoon et al., 2005); 8, E. gaetbuli $(n=1)$ (Yoon et al., 2005). +, Positive reaction; - , negative reaction; w+, weakly positive reaction; ND, not determined; V, variable reaction. Data in parentheses are for the type strain. All species are rod-shaped, positive for catalase and oxidase, and susceptible to chloramphenicol (100 $\mu \mathrm{g}$ per disc; $30 \mu \mathrm{g}$ per disc for E. citreus). All species are Gramnegative, non-sporulating and resistant to polymyxin B (100 U per disc; $300 \mathrm{U}$ per disc for E. citreus).

\begin{tabular}{|c|c|c|c|c|c|c|c|c|}
\hline Characteristic & 1 & 2 & 3 & 4 & 5 & 6 & 7 & 8 \\
\hline Colony colour & Yellow & Orange & $\begin{array}{l}\text { Red or } \\
\text { orange }\end{array}$ & Yellow & Yellow & Orange & $\begin{array}{c}\text { Orange- } \\
\text { yellow }\end{array}$ & $\begin{array}{c}\text { Orange- } \\
\text { yellow }\end{array}$ \\
\hline Motility & - & + & + & - & + & - & - & - \\
\hline Presence of BChl $a$ & - & + & + & - & - & - & - & - \\
\hline Nitrate reduction & - & $\mathrm{v}(+)$ & - & + & - & - & - & - \\
\hline \multicolumn{9}{|l|}{ Hydrolysis of: } \\
\hline Gelatin & - & + & - & $\mathrm{ND}$ & - & - & - & - \\
\hline Starch & $\mathrm{w}+$ & - & - & $(-)$ & + & $\mathrm{v}(+)$ & - & - \\
\hline \multicolumn{9}{|l|}{ Utilization of: } \\
\hline Glucose & + & + & + & $\mathrm{V}(\mathrm{W}+)$ & - & + & + & + \\
\hline Fructose & - & $\mathrm{ND}$ & + & $(-)$ & - & - & - & - \\
\hline Acetate & - & + & + & + & + & + & + & + \\
\hline Citrate & - & $\mathrm{V}(-)$ & - & $\mathrm{V}(\mathrm{w}+)$ & - & - & - & - \\
\hline Formate & - & $\mathrm{V}(-)$ & - & ND & - & - & - & - \\
\hline Pyruvate & + & + & + & - & + & + & + & + \\
\hline Glutamate & - & + & + & $\mathrm{ND}$ & - & - & - & - \\
\hline Succinate & - & $\mathrm{V}(-)$ & + & $\mathrm{ND}$ & - & + & + & + \\
\hline Malate & - & $\mathrm{V}(-)$ & - & - & - & + & - & + \\
\hline \multicolumn{9}{|l|}{ Susceptibility to: } \\
\hline Penicillin G (20 U; 10 U for E. citreus) & + & + & - & $\mathrm{V}(-)$ & - & - & - & - \\
\hline Streptomycin $(50 \mu \mathrm{g} ; 10 \mu \mathrm{g}$ for E. citreus $)$ & - & $\mathrm{V}(-)$ & - & $\mathrm{V}(-)$ & - & - & - & - \\
\hline Optimum growth temperature $\left({ }^{\circ} \mathrm{C}\right)$ & 30 & $25-30$ & $25-30$ & ND & $30-37$ & $30-37$ & $30-35$ & $30-37$ \\
\hline DNA G $+C$ content $(\mathrm{mol} \%)$ & $60 \cdot 3$ & $\begin{array}{l}60-64 \\
(60 \cdot 7)\end{array}$ & 67 & $\begin{array}{c}62 \cdot 0-62 \cdot 4 \\
(62 \cdot 0)\end{array}$ & $\begin{array}{c}64 \cdot 0-64 \cdot 1 \\
(64 \cdot 0)\end{array}$ & $\begin{array}{c}62 \cdot 2-62 \cdot 9 \\
(62 \cdot 2)\end{array}$ & $62 \cdot 2$ & $64 \cdot 5$ \\
\hline
\end{tabular}


Identification System (Sasser, 1990). The DNA G + C content was determined by using the method of Tamaoka \& Komagata (1984) with the modification that the DNA was hydrolysed and the resultant nucleotides were analysed by reversed-phase HPLC. The 16S rRNA gene was amplified by PCR using two universal primers, as described previously (Yoon et al., 1998). Sequencing of the amplified 16S rRNA gene and phylogenetic analysis were performed as described by Yoon et al. (2003).

The morphological, cultural, physiological and biochemical characteristics of strain $\mathrm{SW}-109^{\mathrm{T}}$ are given in the species description (see below) or are shown in Table 1, together with those of some Erythrobacter species. The 16S rRNA gene sequence of strain $\mathrm{SW}-109^{\mathrm{T}}$ determined in this study comprised 1443 nucleotides, representing approximately $96 \%$ of the Escherichia coli 16S rRNA gene sequence. Comparative $16 \mathrm{~S}$ rRNA gene sequence analyses showed that strain $\mathrm{SW}-109^{\mathrm{T}}$ is phylogenetically related to Erythrobacter species (Fig. 1). In the phylogenetic tree based on the neighbour-joining algorithm, strain $\mathrm{SW}-109^{\mathrm{T}}$ joined $E$. seohaensis by a bootstrap confidence level of $62 \cdot 7 \%$ (Fig. 1). Similar tree topologies were found in trees generated with the maximum-likelihood and maximum-parsimony algorithms (data not shown). Levels of 16S rRNA gene sequence similarity between strain $\mathrm{SW}-109^{\mathrm{T}}$ and the type strains of Erythrobacter species ranged from $96.3 \%$ (with E. seohaensis) to $94 \cdot 0 \%$ (with E. litoralis). Sequence similarities with all other species of the family Sphingomonadaceae included in the phylogenetic analysis were lower than $94 \cdot 1 \%$ (Fig. 1).

Chemotaxonomic data support the result of monothetic phylogenetic classification of strain $\mathrm{SW}-109^{\mathrm{T}}$ as a member of the genus Erythrobacter. Strain $\mathrm{SW}-109^{\mathrm{T}}$ contained ubiquinone-10 (Q-10) as the predominant respiratory lipoquinone, at a peak area ratio of approximately $88 \%$. This predominant respiratory lipoquinone was the same as those of Erythrobacter species (Denner et al., 2002; Yoon et al., 2003, 2004, 2005). Strain SW- $109^{\mathrm{T}}$ had a cellular fatty acid profile that contained large amounts of unsaturated, straight-chain and hydroxyl fatty acids; the components $(>1 \%)$ were $\mathrm{C}_{18: 1} \omega 7 c(47 \cdot 7 \%), \mathrm{C}_{16: 1} \omega 7 c$ and/or iso$\mathrm{C}_{15: 0} 2-\mathrm{OH}(13 \cdot 9 \%), \mathrm{C}_{16: 0}(9 \cdot 0 \%), 11-$ methyl- $_{18: 1} \omega 7 c$ $(7 \cdot 1 \%), \mathrm{C}_{17: 1} \omega 6 c(5 \cdot 1 \%), \mathrm{C}_{16: 0} 2-\mathrm{OH}(3 \cdot 6 \%), \mathrm{C}_{14: 0} 2-\mathrm{OH}$ $(3 \cdot 4 \%), \mathrm{C}_{18: 1} \omega 5 c(3 \cdot 4 \%), \mathrm{C}_{16: 1} \omega 5 c(3 \cdot 3 \%)$ and iso- $\mathrm{C}_{16: 0}$ $3-\mathrm{OH}(1 \cdot 0 \%)$. This fatty acid profile was similar to those of the type strains of Erythrobacter species, particularly E. citreus, although there were differences in the proportion of some fatty acids (Denner et al., 2002; Yoon et al., 2003, 2004, 2005). The amounts of each hydroxyl fatty acid allowed differentiation of strain SW- $109^{\mathrm{T}}$ from E. citreus (Supplementary Table in IJSEM Online). The unsaturated fatty acid $\mathrm{C}_{17: 1} \omega 6 \mathrm{c}$ was a minor component in yellowpigmented Erythrobacter species as well as in strain SW$109^{\mathrm{T}}$, while it was a major component in the other Erythrobacter species, except E. longus (Supplementary Table in IJSEM Online). The DNA $\mathrm{G}+\mathrm{C}$ content of strain $\mathrm{SW}-109^{\mathrm{T}}$ was $60 \cdot 3 \mathrm{~mol} \%$.

The phylogenetic distinctiveness is enough to categorize strain $\mathrm{SW}-109^{\mathrm{T}}$ as a species that is distinct from the previously recognized Erythrobacter species (Stackebrandt \& Goebel, 1994). There are differences between strain SW- $109^{\mathrm{T}}$ and other Erythrobacter species in some phenotypic characteristics (Table 1). Strain $\mathrm{SW}-109^{\mathrm{T}}$ is distinguished from one or two yellow-pigmented Erythrobacter species by some phenotypic characteristics, including motility, nitrate reduction, starch hydrolysis and utilization of several substrates (Table 1). Therefore, on the basis of the data presented, strain $\mathrm{SW}-109^{\mathrm{T}}$ should be placed in the genus Erythrobacter as a member of a novel species, for which the name Erythrobacter luteolus sp. nov. is proposed.

\section{Description of Erythrobacter luteolus sp. nov.}

Erythrobacter luteolus (lu.te'o.lus. L. adj. luteolus yellowish).

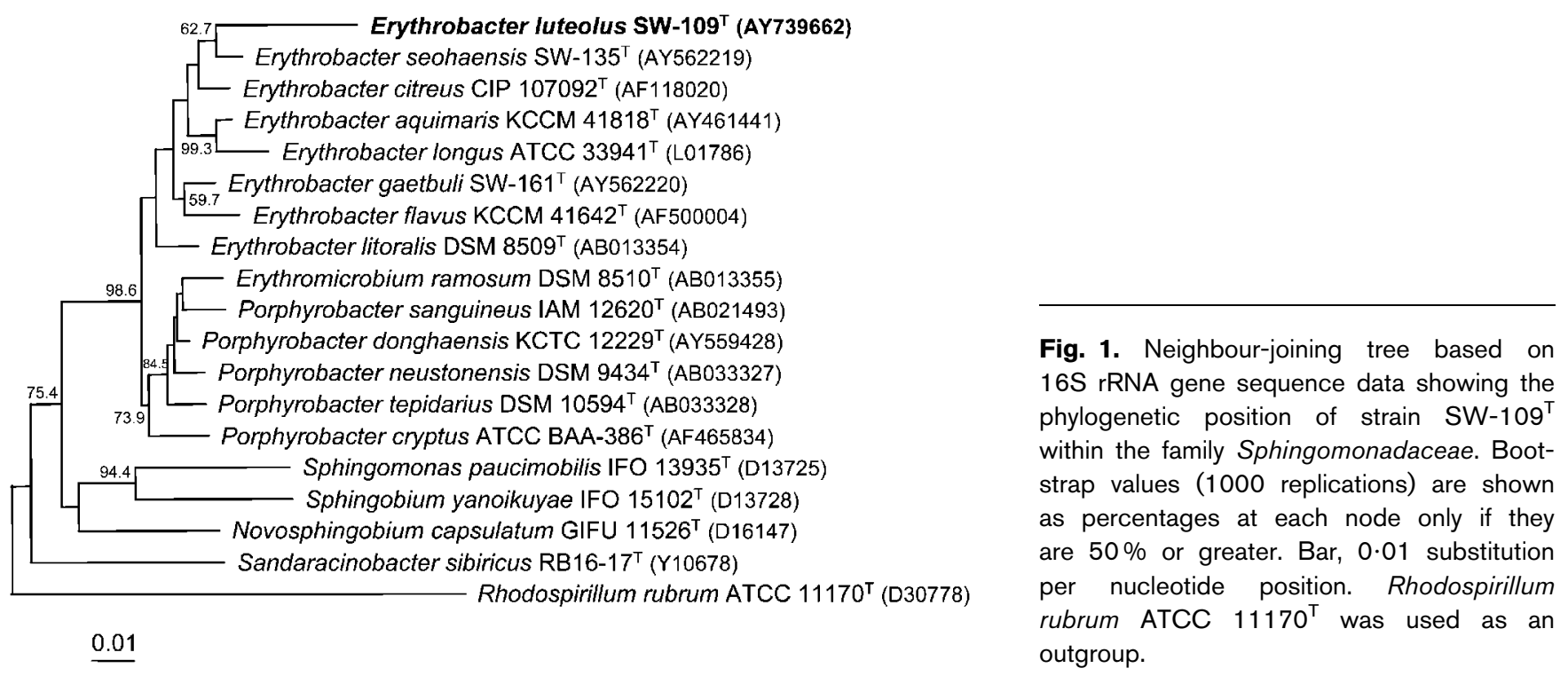


Cells are rod-shaped, $0 \cdot 6-0 \cdot 8 \times 1 \cdot 5-3 \cdot 5 \mu \mathrm{m}$ and non-sporeforming. Colonies on MA are smooth, glistening, circular, convex, yellow in colour and $1 \cdot 0-1.5 \mathrm{~mm}$ in diameter after cultivation for 5 days at $30^{\circ} \mathrm{C}$. Methanol-soluble pigment is characterized by absorption maxima at 332,447 and $473 \mathrm{~nm}$. Growth occurs at 4 and $36^{\circ} \mathrm{C}$, but not at $37^{\circ} \mathrm{C}$. Optimal $\mathrm{pH}$ for growth is $\mathrm{pH} 7 \cdot 0-8 \cdot 0$; growth is observed at $\mathrm{pH} 5 \cdot 5$, but not at $\mathrm{pH} 5 \cdot 0$. Optimal growth occurs in the presence of $2 \%(\mathrm{w} / \mathrm{v}) \mathrm{NaCl}$; growth does not occur without $\mathrm{NaCl}$ or in the presence of $>9 \% \mathrm{NaCl}$. Anaerobic growth does not occur on MA and on MA supplemented with nitrate. Urease-negative. Aesculin, casein, Tweens 20, 40, 60 and 80 and tyrosine are hydrolysed. Hypoxanthine and xanthine are not hydrolysed. $\mathrm{H}_{2} \mathrm{~S}$ is not produced. Acid is produced from D-cellobiose and D-xylose. Acid is not produced from L-arabinose, D-fructose, D-galactose, D-glucose, myo-inositol, lactose, maltose, D-mannitol, Dmannose, D-melezitose, melibiose, D-raffinose, L-rhamnose, D-ribose, D-sorbitol, sucrose or D-trehalose. Maltose, sucrose and D-xylose are utilized; D-cellobiose is weakly utilized, but L-arabinose, D-galactose, D-mannose, Dtrehalose, benzoate and salicin are not utilized. Susceptible to cephalothin, gentamicin and novobiocin, but not to ampicillin or tetracycline. The predominant respiratory lipoquinone is $\mathrm{Q}-10$. The major fatty acid is $\mathrm{C}_{18: 1} \omega 7 c$. Hydroxy fatty acids are detected. The DNA G + C content is $60.3 \mathrm{~mol} \%$ (determined by HPLC). Other phenotypic characteristics are given in Table 1.

The type strain, SW $-109^{\mathrm{T}}\left(=\right.$ KCTC $\left.12311^{\mathrm{T}}=\mathrm{JCM} 12599^{\mathrm{T}}\right)$, was isolated from a tidal flat of the Yellow Sea in Korea.

\section{Acknowledgements}

This work was supported by the 21C Frontier program of Microbial Genomics and Applications (grant MG02-0401-001-1-0-0) from the Ministry of Science and Technology (MOST) of the Republic of Korea and Faculty Research Fund of Sungkyunkwan University.

\section{References}

Bruns, A., Rohde, M. \& Berthe-Corti, L. (2001). Muricauda ruestringensis gen. nov., sp. nov., a facultatively anaerobic, appendaged bacterium from German North Sea intertidal sediment. Int J Syst Evol Microbiol 51, 1997-2006.

Cowan, S. T. \& Steel, K. J. (1965). Manual for the Identification of Medical Bacteria. London: Cambridge University Press.
Denner, E. B. M., Vybiral, D., Kobližžek, M., Kämpfer, P., Busse, H.-J. \& Velimirov, B. (2002). Erythrobacter citreus sp. nov., a yellowpigmented bacterium that lacks bacteriochlorophyll $a$, isolated from the western Mediterranean Sea. Int J Syst Evol Microbiol 52, $1655-1661$.

Komagata, K. \& Suzuki, K. (1987). Lipids and cell-wall analysis in bacterial systematics. Methods Microbiol 19, 161-203.

Lanyi, B. (1987). Classical and rapid identification methods for medically important bacteria. Methods Microbiol 19, 1-67.

Leifson, E. (1963). Determination of carbohydrate metabolism of marine bacteria. J Bacteriol 85, 1183-1184.

Sasser, M. (1990). Identification of Bacteria by Gas Chromatography of Cellular Fatty Acids. Newark, DE: MIDI.

Shiba, T. \& Simidu, U. (1982). Erythrobacter longus gen. nov., sp. nov., an aerobic bacterium which contains bacteriochlorophyll $a$. Int J Syst Bacteriol 32, 211-217.

Stackebrandt, E. \& Goebel, B. M. (1994). Taxonomic note: a place for DNA-DNA reassociation and 16S rRNA sequence analysis in the present species definition in bacteriology. Int J Syst Bacteriol 44, 846-849.

Tamaoka, J. \& Komagata, K. (1984). Determination of DNA base composition by reverse-phase high-performance liquid chromatography. FEMS Microbiol Lett 25, 125-128.

Vybiral, D., Denner, E. B. M., Haller, C. M., Busse, H.-J., Witte, A., Höfle, M. G. \& Velimirov, B. (1999). Polyphasic classification of $0 \cdot 2 \mu \mathrm{m}$ filterable bacteria from the Western Mediterranean Sea. Syst Appl Microbiol 22, 635-646.

Yoon, J.-H., Kim, H., Kim, S.-B., Kim, H.-J., Kim, W. Y., Lee, S. T., Goodfellow, M. \& Park, Y.-H. (1996). Identification of Saccharomonospora strains by the use of genomic DNA fragments and rRNA gene probes. Int J Syst Bacteriol 46, 502-505.

Yoon, J.-H., Lee, S. T. \& Park, Y.-H. (1998). Inter- and intraspecific phylogenetic analysis of the genus Nocardioides and related taxa based on 16S rDNA sequences. Int J Syst Bacteriol 48, 187-194.

Yoon, J.-H., Kim, H., Kim, I.-G., Kang, K. H. \& Park, Y.-H. (2003). Erythrobacter flavus sp. nov., a slight halophile from the East Sea in Korea. Int J Syst Evol Microbiol 53, 1169-1174.

Yoon, J.-H., Kang, K. H., Oh, T.-K. \& Park, Y.-H. (2004). Erythrobacter aquimaris sp. nov., isolated from sea water of a tidal flat of the Yellow Sea in Korea. Int J Syst Evol Microbiol 54, 1981-1985.

Yoon, J.-H., Oh, T.-K. \& Park, Y.-H. (2005). Erythrobacter seohaensis sp. nov. and Erythrobacter gaetbuli sp. nov., isolated from a tidal flat of the Yellow Sea in Korea. Int J Syst Evol Microbiol 55, 71-75.

Yurkov, V., Stackebrandt, E., Holmes, A. \& 7 other authors (1994). Phylogenetic positions of novel aerobic, bacteriochlorophyll a-containing bacteria and description of Roseococcus thiosulfatophilus gen. nov., sp. nov., Erythromicrobium ramosum gen. nov., sp. nov., and Erythrobacter litoralis sp. nov. Int J Syst Bacteriol 44, 427-434. 